\title{
GEORGE FREDERIC STILL
}

\author{
BY \\ Professor CHARLeS McNeIL, M.A., M.D. \\ President, Royal College of Physicians, Edinburgh; President, British \\ Paediatric Association
}

The working life of Sir Frederic Still coincided with an important development in paediatrics-its establishment as a separate field of clinical study and practice; and his own work as clinical investigator, teacher and writer, was a notable contribution to that development. In 1930 he published his 'History of Paediatrics,' and brought the story to the end of the eighteenth century. When in due time the story has been brought up to date, it will be seen that Still, the medical historian, has written by his life and work another chapter in the book. When he went to Great Ormond Street Hospital in the 'nineties of last century, that pioneer institution was only forty years old, but it had been served by a succession of great physicians, and the foundations for further progress had been well laid; and in every important phase of subsequent development, Still's influence can be seen. His great abilities, and his power of detailed accurate work were concentrated on this branch of medicine. The special problems of the child had now been studied in the hospital; and the next steps were their discussion in the club and society, and their teaching in the schools. We find Still, as a young man, Secretary of the Children's Clinical Club, which met in London twice a year, and included among its members Barlow, Eustace Smith, Coutts, Lees, William Osler, John Thomson and Henry Ashby. Still, a trained and careful recorder, kept full minutes of the proceedings, and these minutes may well be useful documents for the future medical historian. In 1906 a more outward sign of growth appeared in his appointment as Professor of Diseases of Children at King's College. Progress was now opened up along both the paths of teaching and critical discussion; and when in 1928 the British Paediatric Association was founded, the choice of its first president naturally fell on Still, now praeclarum et venerabile nomen in British paediatrics. The new Association was strong in itself, in the enthusiasm and good fellowship of its members; and the first meeting was well launched by the reputation and dignity of its president, who in spite of his reserve and reticence in ordinary social intercourse, was ready and well equipped in any technical discussion, and could give to a ceremonial speech the finish and distinction of his literary scholarship. This well-founded clinical reputation, these gifts of mind and speech, were also shown to advantage when he presided at the International Paediatric Congress in 1933. 
Thus in his own clinical work, in his teaching and writing, and in the impact of his work upon others, he was a powerful force in the development of paediatrics in his time. Many others had a share in this development, but he was an outstanding figure. His influential masters were Barlow and Goodhart; he received from them the sound broad clinical tradition of English medicine, and he has handed on that good tradition to his students and successors. And perhaps in his case the teaching he gave by example was even more important than that of precept - the example of patient, thorough, accurate clinical work, of fastidious care in his writing begotten of his classical training; and of his strong and upright character, reserved towards his fellow men, but showing its tenderness and playfulness in his contact with children.

In his last literary testament, ' Childhood and other Poems,' published just before his death, Still sprang a surprise on his contemporaries, and showed that he had in his many-sided personality a vein of poetry, and one that he must have worked unobserved for many years. It is not unlikely that these verses will keep a place in English literature for they bear not only the stamp of scholarly workmanship, but also of a deep feeling for children. And in English medicine his 'History of Paediatrics' will certainly survive, whatever may be the fate of his other medical writings. As for that part of a man's work that is unrecorded, but passes into the texture of other minds and bears fruit in their actions, the name and work of Still will endure. His work was done at a time when a new phase in paediatrics was beginning: and in that phase he played a leading part, receiving the tradition of older physicians, moulding it, and handing it on to his successors. Quasi cursores tradunt lampades. Still loved the classical brevity: both as a scholar and a man he would be content with these four Latin words for his epitaph. 